\title{
A case of Cornelia de Lange syndrome from Sudan Mona Ellaithi* ${ }^{* 1,2}$, David Gisselsson ${ }^{\dagger 3}$, Therese Nilsson ${ }^{\dagger 3}$, Atif Elagib ${ }^{4}$, Imad Fadl-Elmula ${ }^{5}$ and Mashair Abdelgadir ${ }^{\dagger 6}$
}

\begin{abstract}
Address: ${ }^{1}$ The Orchids Organization for Children with Special Needs, Khartoum, Sudan, ${ }^{2}$ Institute of Endemic Diseases, University of Khartoum, Khartoum, Sudan, ${ }^{3}$ Department of Clinical Genetics, Lund University, Lund, Sweden, ${ }^{4}$ Tropical Medical Research Institute, Khartoum, Sudan, ${ }^{5}$ Faculty of Medical Laboratory Sciences, Al Neelain University, Khartoum, Sudan and ${ }^{6}$ Khartoum Teaching Hospitals, Khartoum, Sudan

Email: Mona Ellaithi* - Ellaithi_Mona@yahoo.com; David Gisselsson - David.Gisselsson@med.lu.se;

Therese Nilsson - Therese.Nilsson@med.lu.se; Atif Elagib - Atifelagib@ hotmail.com; Imad Fadl-Elmula - fadl-elmula@prime-scientific.com; Mashair Abdelgadir - Rahaf72@hotmail.com

* Corresponding author †Equal contributors
\end{abstract}

Published: 29 January 2007

BMC Pediatrics 2007, 7:6 doi:10.1 |86/147|-243|-7-6
Received: 13 August 2006

Accepted: 29 January 2007

This article is available from: http://www.biomedcentral.com/|47/-243I/7/6

(C) 2007 Ellaithi et al; licensee BioMed Central Ltd.

This is an Open Access article distributed under the terms of the Creative Commons Attribution License (http://creativecommons.org/licenses/by/2.0), which permits unrestricted use, distribution, and reproduction in any medium, provided the original work is properly cited.

\begin{abstract}
Background: Brachmann de Lange syndrome (BDLS) is a multiple congenital anomaly syndrome characterized by a distinctive facial appearance, prenatal and postnatal growth deficiency, psychomotor delay, behavioral problems, and malformations of the upper extremities.

Case presentation: Here we present for the first time a case of BDLS from Sudan, a 7-monthold female infant, who was referred as a case of malnutrition. The patient was from a Sudanese western tribe. Clinical investigation showed that the child was a classical case of BDLS, but with some additional clinical findings not previously reported including crowded ribs and tied tongue.
\end{abstract}

Conclusion: Reporting BDLS cases of different ethnic backgrounds could add nuances to the phenotypic description of the syndrome and be helpful in diagnosis.

\section{Background}

Brachmann de Lange Syndrome (BDLS) [1], also known as Cornelia de Lange syndrome [2] or Brachmann Cornelia de Lange syndrome is a dominantly inherited multisystem developmental disorder characterized by growth and cognitive retardation, abnormalities of the upper limbs, gastroesophageal dysfunction, ophthalmologic and genitourinary anomalies, hirsutism, characteristic facial features, pyloric stenosis, congenital diaphragmatic hernias, cardiac septal defects, and hearing loss. Autism and self-injurious tendencies also frequently occur. The prevalence of the syndrome is estimated to be as high as 1 in 10,000 [3]. Facial findings, including characteristic eyebrows (neat, well-defined, and arched), long philtrum, thin lips, and crescent-shaped mouth, are the most impor- tant diagnostic features of BDLS. This combination of facialanomalies is absent in postpubertal males but not in postpubertal females [4].

Van Allen and colleagues in 1993, proposed a classification system for BDLS. Type I, or classic BDLS, patients have the characteristic facial and skeletal changes of the diagnostic criteria established by Preus and Rex in 1983 $[5,6]$. They have prenatal growth deficiency, moderate-toprofound psychomotor retardation, and major malformations, which result in severe disability or death. Type II, or mild BDLS, patients have similar facial and minor skeletal abnormalities to those seen in type I; however, these changes may develop with time or may be only partially expressed. They have mild-to-borderline psychomotor 
retardation, less severe pre- and postnatal growth deficiency, and the absence of (or less severe) major malformations. Type III, or phenocopy BDLS, includes patients who have phenotypic manifestations of BDLS that are causally related to chromosomal alterations or teratogenic exposures. Allanson and colleagues in 1997 concluded that, in the mild phenotype, the characteristic facial appearance may not appear until 2 to 3 years of age, while it is always present at birth in the classic phenotype. They also noted that the characteristic facial appearance decreased with time in the mild phenotype. Craniofacial pattern profiles showed that both type I and type II groups had microbrachycephaly, but that the dimensions of the mild group were somewhat closer to normal [7].

In rare cases, constitutional chromosomal imbalances can simulate the features of BDLS. For example, DeScipio and colleagues in 2005 reported 2 half-sibs with clinical features suggestive of BDLS and an unbalanced chromosomal rearrangement, $\operatorname{der}(3) \mathrm{t}(3 ; 12)(\mathrm{p} 25.3 ; \mathrm{p} 13.3)$, inherited from a balanced translocation in their unaffected mother [8]. The sibs had many features consistent with BDLS, including microcephaly, growth retardation, mental retardation, hirsutism, synophrys, anteverted nares, single palmer creases, and syndactyly of toes 2 and 3 , but also showed significant clinical overlap with del(3)(p25) syndrome. However, the vast majority of BDLS cases have normal karyotypes by chromosome banding. Ptacek and colleagues in 1963 suggested dominant inheritance [9], but Opitz in 1971 and 1985 thought recessive inheritance more likely $[10,11]$. Robinson and Jones in 1983 supported the conclusion that BDLS is autosomal dominant and that the sporadic occurrence in most cases reflects the genetic lethality of the disorder. Their cases were a severely affected 5-month-old boy and his mildly affected 24-year-old mother [12]. Although most cases are sporadic, rare families with multiple affected sibs have been described [13]. Fryns and colleagues in 1987 reported 2 infant brothers with a severe form of the syndrome. They died at the ages of 3 months and 3 weeks, respectively. The parents were normal, and prometaphase chromosome studies failed to show any abnormality [14]. In the same year Naguib and colleagues described an Arab family with phenotypically normal first-cousin parents and 2 offspring showing variable features of this disorder. The proband had apparently normal chromosomes and died at the age of 3 months. His sister was less severely affected and lived for 6 years. The authors suggested recessive inheritance [15]. McConnell and colleagues in 2003 supported the dominant inheritance theory, reporting a family with a neonate affected by classical BDLS, an affected mother, and a probably affected maternal grandmother [16].
Krantz and colleagues in 2004, and also Tonkin in 2004 performed genome-wide linkage exclusion mapping in 12 BDLS families and identified a locus in chromosome band 5p13. This locus mapped close to both a translocation breakpoint and a small de novo deletion associated with BDLS. Further mapping of the 5p13 translocation breakpoint showed disruption of the NIPBL gene $[3,17]$. Recently, Yan and colleagues identified 13 NIPBL mutations identified in 28 unrelated Polish BDLS patients. Mutation-positive patients were more severely affected in comparison to mutation negative individuals with respect to weight, height, and mean head circumference at birth, facial dysmorphism and speech impairment. Analyses of combined data from this and the two previous studies revealed that the degree of growth retardation, developmental delay and limb defects showed significant differences between patients with and without mutations and between patients with missense and truncating mutations, whereas only a portion of these features differed significantly in any individual study [18]. Bhuiyan and colleagues in 2006 described genotype-phenotype correlations in 39 patients. They found mutations of NIPBL in $56 \%$ of the patients. Truncating mutations generally caused a more severe phenotype, but this correlation was not absolute [19]. Musio and colleagues (2006) recruited 53 unrelated and 4 related individuals with a diagnosis of BDLS, encompassing the entire spectrum of phenotypes. They found pathogenic NIPBL mutations in 24 of them, whereas the remaining 33 cases did not have any NIPBL alterations. Of these 33 individuals, there was only 1 instance of familial occurrence, with 2 male sibs, their mother, and a first cousin affected. Involvement of NIPBL was excluded in this family, but the affected individuals were found to carry a 3-bp deletion in the SMC1L1 gene in Xp11. In addition, a sporadic case was found to have a de novo miss-sense mutation in the same gene [20]. Thus, approximately half of patients with BDLS features in a European population appear to exhibit NIPBL mutations, whereas the remaining cases may be caused by other mechanisms including X-linked genes and chromosomal imbalances. Only few cases of BDLS have been reported from countries outside Europe and North America $[21,22]$.

\section{Case presentation Case history}

A 7-month-old female infant from a Sudanese western tribe was referred as a case of malnutrition. At presentation, the patient had confluent eyebrows that appeared arched and well-defined, long curly eyelashes, low front and back hairlines, turned-up nose, down-turned angles of the mouth and thin lips, long philtrum, small lower jaw and protruding upper jaw, microcephaly, excessive body hair, short neck, and small broad hands with simian crease and proximal insertion of the thumb, and clinodac- 
tyly of the fifth finger. X-ray showed delayed bone development. She had low-pitched cry, short neck with limited movement, stiff muscle tone (unable to sit, she was still fisting), fixed flexion of both elbows, and she did not show any sign of speaking or babble (Fig. 1 and 2). Moreover she had tied tongue and thin skin. Her brain stem evoked potential test showed conductive hearing loss. She was about 27 inches in length, her weight was 3 kilograms and there were no records about her birth weight. Her skull circumference was $35 \mathrm{~cm}$. Finally, she showed a number of features not typical of BDLS, including crowded ribs by chest by X-ray (distance between each rib is short). Hepatomegally was shown by ultrasonography.

\section{Cytogenetic analysis}

Peripheral blood from the patient was subjected to shortterm culture in RPMI 1640 medium for 72 hours. After metaphase arrest through exposure to Colcemide, cells were harvested, treated with hypotonic solution, and then fixed with methanol and acetic acid according to standard procedures. The harvested cells were dropped on clean slides and stained with Wright's stain, for chromosome banding [23]. The clonality criteria and the karyotypic descriptions were according to the ISCN recommendations [24]. Analysis of 11 metaphase cells showed 46, XX in all cells.

\section{Conclusion}

Diagnosis of BDLS is dependent on the recognition of distinctive facial features [25], in addition to the physical features as pre- and postnatal growth retardation, microcephaly, severe mental retardation with speech delay, feeding problems, major malformations including limb defects, and characteristic facial features [26]. Because of the characteristic facial features the physiological findings, and the presence of a normal karyotype, the patient was diagnosed as type I BDLS [5]. She had feeding problems, which is common in BDLS, and this resulted in

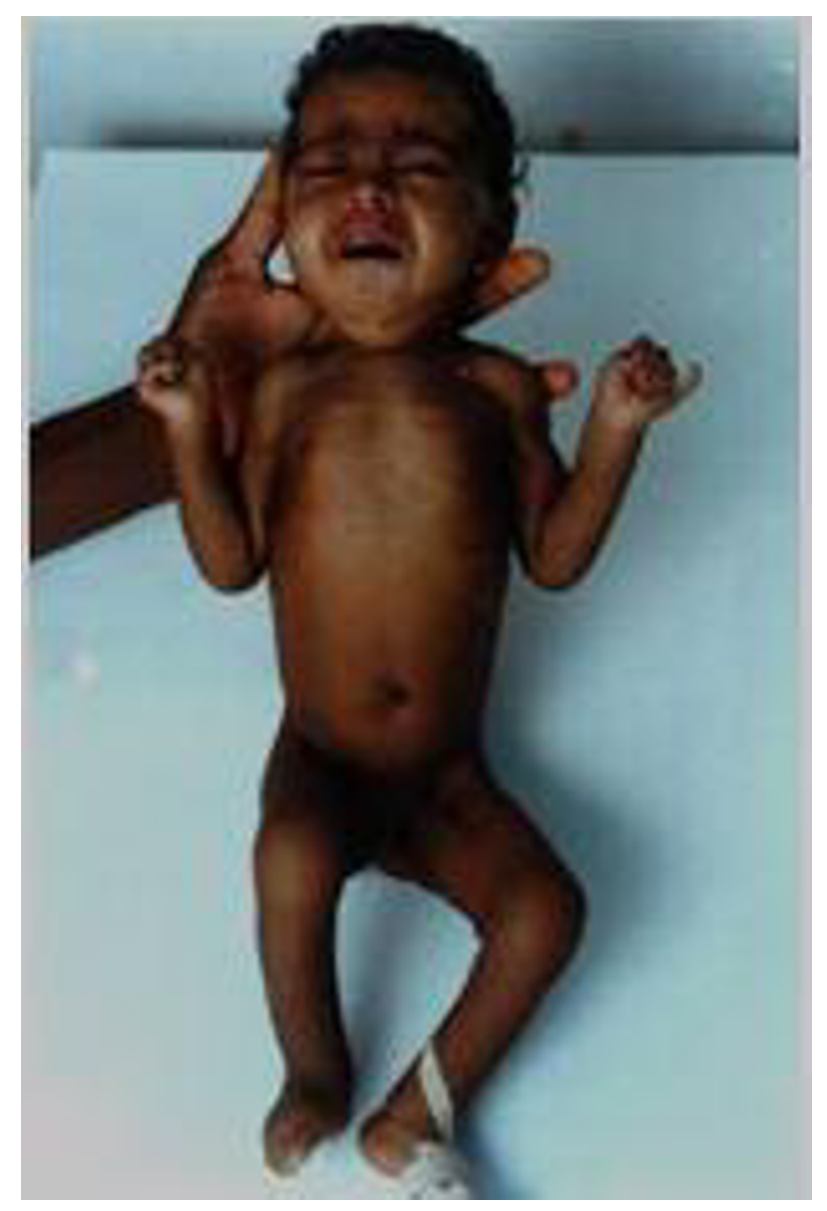

\section{Figure I}

The patient external features: long curly eyelashes, low front and back hairlines, turned-up nose, down-turned angles of the mouth and thin lips, long philtrum, small lower jaw and protruding upper jaw, microcephaly, excessive body hair, short neck. 


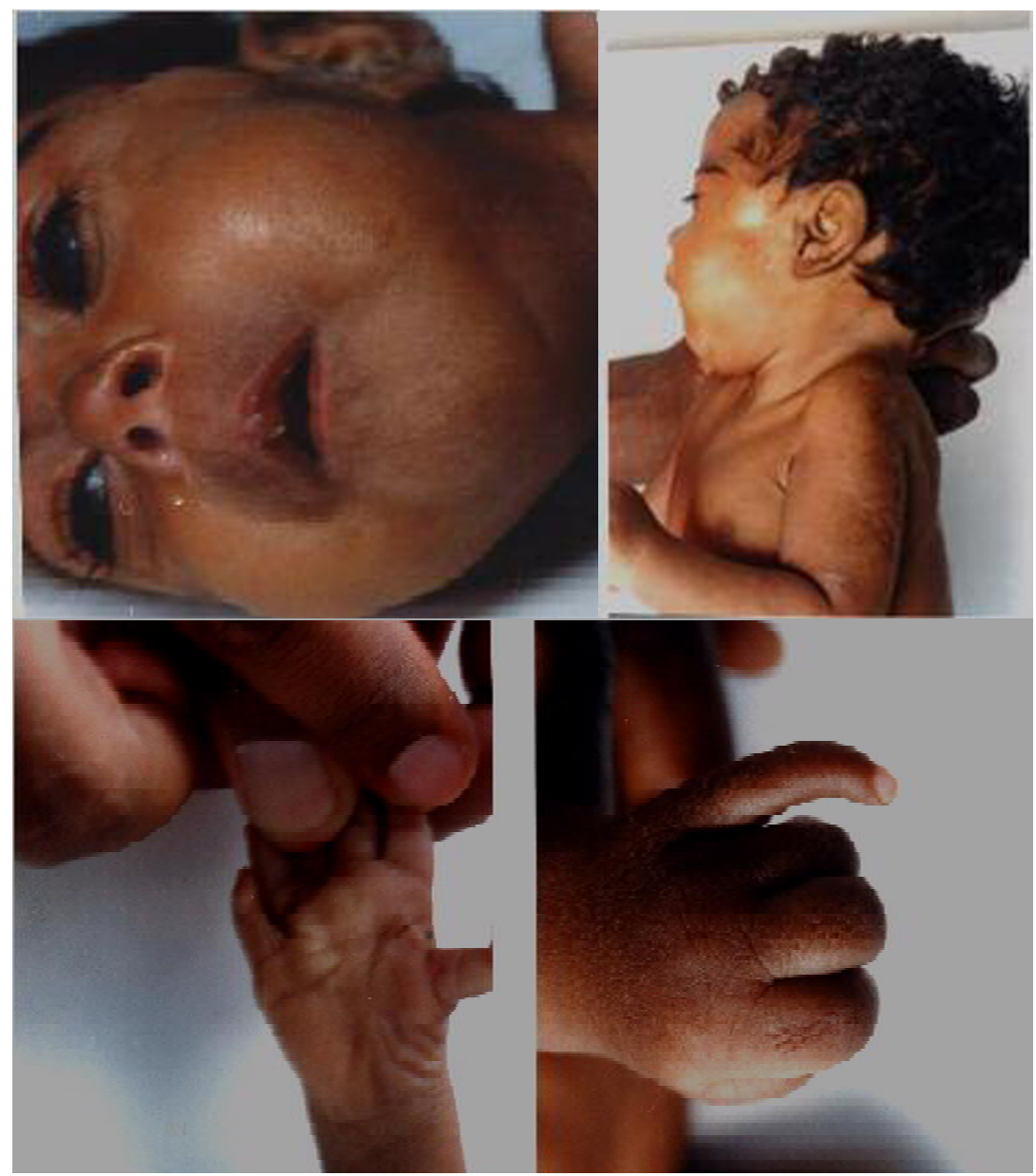

\section{Figure 2}

Close view of the patients facial features $(a, b)$. The patient shows small broad hands with simian crease and proximal insertion of the thumb, and clinodactyly of the fifth finger (c, d).

the malnutrition for which she was originally referred to a pediatrician. Other physiological findings supporting the diagnosis were microcephaly, excessive body hair, short neck, small broad hands with simian crease and proximal insertion of the thumb, clinodactyly of the fifth finger, short neck with limited movement, stiff muscle tone (unable to sit, she was still fisting), fixed flexion of both elbows, and delayed bone development. She had a lowpitched cry and did not show any sign of speaking or babble. The patient also showed features that were not typical of BDLS, including tied tongue, and crowded ribs. She also had hepatomegaly and decreased subcutaneous fat, which was most probably secondary to her feeding problems.

Chromosomal analysis was performed to find out if there were chromosomal imbalances or gross rearrangements of the NIPBL or SMC1L1 gene regions. The karyotype was normal. Analyses for mutations in the NIPBL and
SMC1L1 genes are not currently available in Sudan and there were no funds for testing abroad. Nevertheless, based on clinical features, we believe the present patient to be the first BDLS case reported in the Sudan. Rreporting BDLS cases of different ethnic backgrounds could add nuances to the phenotypic description of the syndrome and be helpful in diagnosis. Taken together with previous reports from our laboratory [27], 28], it underscores the value of cytogenetic techniques and clinical genetic services also in low-income countries.

\section{Competing interests}

The author(s) declare that they have no competing interests.

\section{Authors' contributions}

ME has collected the sample, cultured it, and harvested metaphase chromosomes in the Institute of Endemic Diseases, University of Khartoum, Sudan; ME has also partic- 
ipated in the design and coordination of the study and drafted the manuscript. DG and TN performed the cytogenetic analysis, participated in the design of the study, and helped to draft the manuscript. AE and IF participated in the design of the study, and helped to draft the manuscript. MA diagnosed the case in Khartoum teaching hospital, supervised all the clinical investigations, participated in design of the study and helped in drafting of the manuscript. All authors agreed on the final revision of the paper.

\section{Acknowledgements}

We are grateful to the Alf Hanssons minnesfond, the ASTRA-Zeneca traveling fund, the Lund Medical Society and the Royal Physiographic Society of Lund. Written consent was obtained from the patient's family for publication of this study.

\section{References}

I. Brachmann W: Ein fall von symmetrischer monodaktylie durch Ulnadefekt, mit symmetrischer flughautbildung in den ellenbeugen, sowie anderen abnormitaten (zwerghaftogkeit, halsrippen, behaarung). Jarb Kinder Phys Erzie 1916, 84:225-235.

2. De Lange C: Sur un type nouveau de degenerescence (typus Amstelodamensis). Arch Med Enfants 1933, 36:713-719.

3. Krantz ID, McCallum J, DeScipio C, Kaur M, Gillis LA, Yaeger D, Jukofsky L, Wasserman N, Bottani A, Morris CA, Nowaczyk MJ, Toriello H, Bamshad MJ, Carey JC, Rappaport E, Kawauchi S, Lander AD, Calof AL, Li HH, Devoto M, Jackson LG: Cornelia de Lange syndrome is caused by mutations in NIPBL, the human homolog of Drosophila melanogaster Nipped-B. Nat Genet 2004, 36:631-635.

4. Ireland M, Burn J: Cornelia de Lange syndrome - photo essay. Clin Dysmorph 1993, 2:151-160.

5. Van Allen MI, Filippi G, Siegel-Bartelt J, Yong SL, McGillivray B, Zuker RM, Smith CR, Magee JF, Ritchie S, Toi A, Reynolds JF: Clinical variability within Brachmann-de Lange syndrome: a proposed classification system. Am J Med Genet 1993, 47:947-958.

6. Preus M, Rex AP: Definition and diagnosis of the Brachmannde Lange syndrome. Am J Med Genet 1983, 16:301-312.

7. Allanson JE, Hennekam RCM, Ireland M: De Lange syndrome: subjective and objective comparison of the classical and mild phenotypes. J Med Genet 1997, 34:645-650.

8. DeScipio C, Kaur M, Yaeger D, Innis JW, Spinner NB, Jackson LG, Krantz ID: Chromosome rearrangements in Cornelia de Lange syndrome (CdLS): report of a $\operatorname{der}(3) t(3 ; 12)(p 25.3 ; p \mid 3.3)$ in two half sibs with features of CdLS and review of reported CdLS cases with chromosome rearrangements. Am J Med Genet 2005, I37A:276-282.

9. Ptacek LJ, Opitz JM, Smith DW, Gerritsen T, Waisman HA: The Cornelia de Lange syndrome. J Pediat 1963, 63:1000-1020.

10. Opitz JM: The Brachmann-de Lange syndrome. Am J Med Genet 1985, 22:89-102.

II. Opitz JM: Comment. In Year Book of Pediatrics Edited by: Gellis SS. Chicago: Year Book Med. Publ. (pub); I971:489.

12. Robinson LK, Jones KL: The de Lange syndrome in a mother and her son. (Abstract). Proc Greenwood Genet Center 1983, 2: 125.

13. Borghi A, Giusti G, Bigozzi U: Nanismo degenerativo tipo di Amsterdam (typus Amstelodamensis-malattia di Cornelia de Lange): presentazione di un caso e considerazioni di ordine genetico. Acta Genet Med Gemellol 1954, 3:365-372.

14. Fryns JP: Hernie diaphragmatique postero-laterale et syndrome de Brachmann-de Lange. (Letter). Arch Franc Pediat 1987, 44:473-474.

15. McConnell V, Brown T, Morrison PJ: An Irish three-generation family of Cornelia de Lange syndrome displaying autosomal dominant inheritance. Clin Dysmorphol 2003, I 2:241-244.

16. Tonkin ET, Wang TJ, Lisgo S, Bamshad MJ, Strachan T: NIPBL, encoding a homolog of fungal Scc2-type sister chromatid cohesion proteins and fly Nipped-B, is mutated in Cornelia de Lange syndrome. Nat Genet 2004, 36:636-4I.
17. Yan J, Saifi GM, Wierzba TH, Withers M, Bien-Willner GA, Limon J, Stankiewicz P, Lupski JR, Wierzba J: Mutational and genotypephenotype correlation analyses in 28 Polish patients with Cornelia de Lange syndrome. Am J Med Genet 2006, I40A: I53|-|54|.

18. Bhuiyan ZA, Klein M, Hammond $P$, van Haeringen $A$, Mannens MMAM, Van Berckelaer-Onnes I, Hennekam RCM: Genotype-phenotype correlations of 39 patients with Cornelia de Lange syndrome: the Dutch experience. J Med Genet 2006, 43:568-575.

19. Musio A, Selicorni A, Focarelli ML, Gervasini C, Milani D, Russo S, Vezzoni P, Larizza L: X-linked Cornelia de Lange syndrome owing to SMCILI mutations. Nat Genet 2006, 38:528-530.

20. Bhuiyan ZA, Zilfalil BA, Hennekam RC: A Malay boy with the Cornelia de Lange syndrome: clinical and molecular findings. Singapore Med J 2006, 47:724-7.

21. Temtamy SA, Shoukry AS: Cornelia de Lange syndrome in an Egyptian child. Birth Defects Orig Artic Ser 1975, I I:362-3.

22. MJ Barch: Peripheral blood culture. In Barch MJ, Lawce HJ, Arsham MS, editors, The ACT Cytogenetics Laboratory Manual 2nd edition. Raven Press Ltd, New York; 1991.

23. F Mitelman: ISCN: An International System for human Cytogenetic Nomenclature. Ed S Karger Base 1995.

24. Ireland M, Donnai D, Burn J: Brachmann-de Lange syndrome: delineation of the clinical phenotype. Am J Med Genet 1993, 47:959-964.

25. Jackson L, Kline AD, Barr MA, Koch S: de Lange syndrome: a clinical review of 310 individuals. Am J Med Genet 1993, 47:940-6.

26. Ellaithi M, Nilsson T, Gisselsson D, Elagib A, Eltigani H, Fadl-Elmula I: Female genital mutilation of a karyotypic male presenting as a female with delayed puberty. BMC Women's Health 2006, 6:6 [http://www.biomedcentral.com/bmcwomenshealth].

27. Ellaithi M, Gisselsson D, Nilsson T, Abd El-Fatah S, Ali T, Elagib A, Ibrahim ME, Fadl-Elmula I: A $\operatorname{del}(\mathbf{X})(\mathbf{p I I})$ carrying SRY sequences in an infant with ambiguous genitalia. BMC Pediatr 2006, 6: II.

\section{Pre-publication history}

The pre-publication history for this paper can be accessed here:

http://www.biomedcentral.com/1471-2431/7/6/prepub

Publish with Biomed Central and every scientist can read your work free of charge

"BioMed Central will be the most significant development for disseminating the results of biomedical research in our lifetime. "

Sir Paul Nurse, Cancer Research UK

Your research papers will be:

- available free of charge to the entire biomedical community

- peer reviewed and published immediately upon acceptance

- cited in PubMed and archived on PubMed Central

- yours - you keep the copyright

Submit your manuscript here:

http://www.biomedcentral.com/info/publishing_adv.asp
BioMedcentral 